\title{
Low-Titer Cold Agglutinin Disease with Systemic Sclerosis
}

\author{
Miki Oshima, Hiroyuki MaEdA, Keiko Morimoto, Masao DoI and Masao KuwABARA
}

\begin{abstract}
A 60-year-old woman with systemic sclerosis (SSc) was admitted because of severe anemia and Raynaud's phenomenon. Her anemia was associated with a low serum haptoglobin level and positive results of direct Coomb's tests, which indicated the presence of autoimmune hemolysis. Other laboratory investigations revealed positive anti-nuclear antibodies, anti-topoisomerase antibody, cold agglutinins, as well as low serum levels of IgM, C3, $\mathrm{C} 4$ and CH50. Bone marrow aspiration showed discrete hyperplasia of the erythropoietic system. She was diagnosed as low-titer cold agglutinin disease rousing secondarily to SSc. The anemia was alleviated with the oral administration of prednisolone. This case emphasized, in terms of pathogenesis, the close association between systemic rheumatic diseases and hematological abnormalities evoked by autoimmunity.

(Internal Medicine 43: 139-142, 2004)
\end{abstract}

Key words: Raynaud's phenomenon, autoimmune hemolytic anemia, low titer cold agglutinin disease, systemic sclerosis

\section{Introduction}

Cold agglutinin disease (CAD) is a type of autoimmune hemolytic anemia (AIHA), in which, cold agglutinins, the autoantibodies against erythrocyte carbohydrate antigens, play pathogenic roles $(1,2)$. At decreased ambient temperatures, cooling of the peripheral circulation allows binding of the cold agglutinins to erythrocytes, which is responsible for the symptoms of peripheral intravascular hemagglutination with cold-induced pallor and acrocyanosis (1-3). Complement activation by IgM cold agglutinins causes hemolytic anemia (4). We herein describe a rare case of low titer CAD rousing in a patient suffering from SSc, who presented with anemia, acrocyanosis and Raynaud's phenomenon on cold exposure. She was successfully treated with noncytotoxic agents, although her manifestations of anemia were serious.

\section{Case Report}

A 60-year-old woman with SSc was admitted to our hospital in Feburary 2002 because of serious anemia, acrocyanosis and Raynaud's phenomenon on cold exposure. She had been diagnosed as having SSc from the pathological findings of a skin biopsy in 1995, and had been taking daily $10 \mathrm{mg}$ oral prednisolone for the pulmonary fibrosis and skin involvements. Although her condition had been well controlled for years, in the winter of 2002, her Raynaud's phenomenon worsened initially as the ambient temperature went down. Then acrocyanosis appeared with the further exacerbation of Raynaud's phenomenon. On admission, a physical examination revealed blood pressure 110/60 mmHg and heart rate 120/minute. A chest X-ray showed a slight fibrotic change of both lungs, and an abdominal sonography revealed a mild hepato-splenomegaly. The laboratory findings (Table 1) revealed severe anemia with reticulocytosis. Other abnormal results included elevated serum level of $\mathrm{LDH}$ (isozyme 1, 2 dominant), indirect bilirubin, and aldolase. The serum concentration of $\operatorname{IgG}, \operatorname{IgA}$ and ferritin were normal, whereas those of $\mathrm{IgM}, \mathrm{C} 3, \mathrm{C} 4, \mathrm{CH} 50$, and haptoglobin were low. The anti-nuclear antibodies were positive (titer $1: 320$ ) with homogenous and speckled patterns, which were negative $(1: 64)$ before the exacerbation of her disease. Simultaneously, serum anti-topoisomerase antibodies were higher than they were before the exacerbation, whilst the anti-double-strand DNA antibody, anti-RNP antibody, and anti-SM antibody remained negative. The cold agglutinins were positive at a titer of $1: 256$ at a temperature of $25^{\circ} \mathrm{C}$. The serological tests were negative for mycoplasma, Epstein-Barr virus, and cryoglobulins. Both direct and indirect Coomb's tests were positive. The former was positive with anti-C3b and anti-C3d, and negative with antiIgG antisera. Serum agarose electrophoresis with immunofixation revealed the absence of monoclonal immunoglobulins (M-components). Bone marrow aspiration (Fig. 1)

From Department of Respiratory Medicine and Rheumatology, Hiroshima Prefectural Hospital, Hiroshima

Received for publication February 17, 2003; Accepted for publication September 20, 2003

Reprint requests should be addressed to Miki Oshima, Department of Respiratory Medicine and Rheumatology, Hiroshima Prefectural Hospital, 1-5-54 Ujina-kanda, Minami-ku, Hiroshima 734-8530 
Table 1. Laboratory Data on Admission

\begin{tabular}{|c|c|c|c|c|c|c|}
\hline \multicolumn{7}{|l|}{ Hematology } \\
\hline WBC & $6,300 / \mu \mathrm{l}$ & $\mathrm{TP}$ & $6.4 \mathrm{~g} / \mathrm{dl}$ & & Anti-nuclear Ab & $320 \times$ \\
\hline Neu & $70.5 \%$ & $\mathrm{~A} 1-\mathrm{Gg}$ & $0.47 \mathrm{~g} / \mathrm{dl}$ & $7.4 \%$ & Anti-topoisomerase $\mathrm{Ab}$ & 30.4 ID \\
\hline Eo & $0.5 \%$ & A2-Gg & $0.33 \mathrm{~g} / \mathrm{dl}$ & $5.1 \%$ & $\mathrm{C} 3$ & $57 \mathrm{mg} / \mathrm{dl}$ \\
\hline Lym & $24.5 \%$ & $\mathrm{~B}-\mathrm{Gg}$ & $0.63 \mathrm{~g} / \mathrm{dl}$ & $9.8 \%$ & $\mathrm{C} 4$ & $4 \mathrm{mg} / \mathrm{dl}$ \\
\hline Мо & $2.5 \%$ & G-Gg & $1.86 \mathrm{~g} / \mathrm{dl}$ & $29.0 \%$ & CH50 & $15.3 \mathrm{U} / \mathrm{m}$ \\
\hline $\mathrm{RBC}$ & $165 \times 10^{4} / \mu 1$ & $\mathrm{Alb}$ & $3.1 \mathrm{~g} / \mathrm{dl}$ & $48.6 \%$ & Cold agglutinin & 256 dills \\
\hline $\mathrm{Hb}$ & $6.1 \mathrm{~g} / \mathrm{dl}$ & BUN & $28.8 \mathrm{mg} / \mathrm{dl}$ & & Cryoglobulin & + \\
\hline $\mathrm{Ht}$ & $17.1 \%$ & $\mathrm{Cr}$ & $0.5 \mathrm{mg} / \mathrm{dl}$ & & Mycoplasma (PA) & $40 x$ \\
\hline $\mathrm{MCV}$ & $103.0 \mathrm{um}^{3}$ & $\mathrm{Na}$ & $41 \mathrm{mEq} / \mathrm{l}$ & & EB IgG (VCA) & $320 x$ \\
\hline MCHC & $35.5 \%$ & $\mathrm{~K}$ & $3.7 \mathrm{mEq} / \mathrm{l}$ & & EB IgM (VCA) & $10 x$ \\
\hline Plt & $20.5 \times 10^{4} / \mu 1$ & $\mathrm{Cl}$ & $111 \mathrm{mEq} / \mathrm{l}$ & & EBNA & $80 x$ \\
\hline Reticulocytes & $360 / 1,000$ & CRP & $0.4 \mathrm{mg} / \mathrm{dl}$ & & HBs-Ag & - \\
\hline Serology & & CPK & $66 \mathrm{mU} / \mathrm{ml}$ & & $\mathrm{HCV}-\mathrm{Ab}$ & - \\
\hline GOT & $32 \mathrm{IU}$ & FBS & 96 mg/dl & & Wassermann reaction & - \\
\hline GPT & $16 \mathrm{IU}$ & $\mathrm{Fe}$ & $148 \mathrm{ug} / \mathrm{dl}$ & & CEA & 3.6 \\
\hline LDH & $1,054 \mathrm{IU}$ & UIBC & $164 \mathrm{ug} / \mathrm{dl}$ & & $\mathrm{ng} / \mathrm{ml}$ & \\
\hline LDH1 & $37 \%$ & Ferritin & $485 \mathrm{ng} / \mathrm{ml}$ & & CA 19-9 & $37 \mathrm{U} / \mathrm{ml}$ \\
\hline LDH2 & $39 \%$ & Vit-B12 & $1,100 \mathrm{ng} / \mathrm{ml}$ & & Coagulation test & \\
\hline LDH3 & $16 \%$ & Folic Acid & $4.6 \mathrm{ng} / \mathrm{ml}$ & & $\overline{\mathrm{PT}}$ & $11.2 \mathrm{sec}$ \\
\hline LDH4 & $5 \%$ & Haptoglobin & $<10 \mathrm{mg} / \mathrm{dl}$ & & aPTT & $30.3 \mathrm{sec}$ \\
\hline LDH5 & $3 \%$ & Aldolase & $10.5 \mathrm{IU} / l$ & & Urine test & \\
\hline ALP & $177 \mathrm{IU}$ & $\lg G$ & $1,290 \mathrm{mg} / \mathrm{dl}$ & & Protein & - \\
\hline T. Bil & $1.4 \mathrm{mg} / \mathrm{dl}$ & $\operatorname{lgM}$ & $605 \mathrm{mg} / \mathrm{dl}$ & & Glucose- & \\
\hline ID. Bil & $1.0 \mathrm{mg} / \mathrm{dl}$ & $\lg A$ & $218 \mathrm{mg} / \mathrm{dl}$ & & $\mathrm{Ob}$ & - \\
\hline LAP & $41 \mathrm{mU} / \mathrm{ml}$ & ESR & $157 / 164 \mathrm{~mm}$ & & WBC & - \\
\hline$\gamma$-GTP & $16 \mathrm{mU} / \mathrm{ml}$ & & & & Bil & - \\
\hline
\end{tabular}

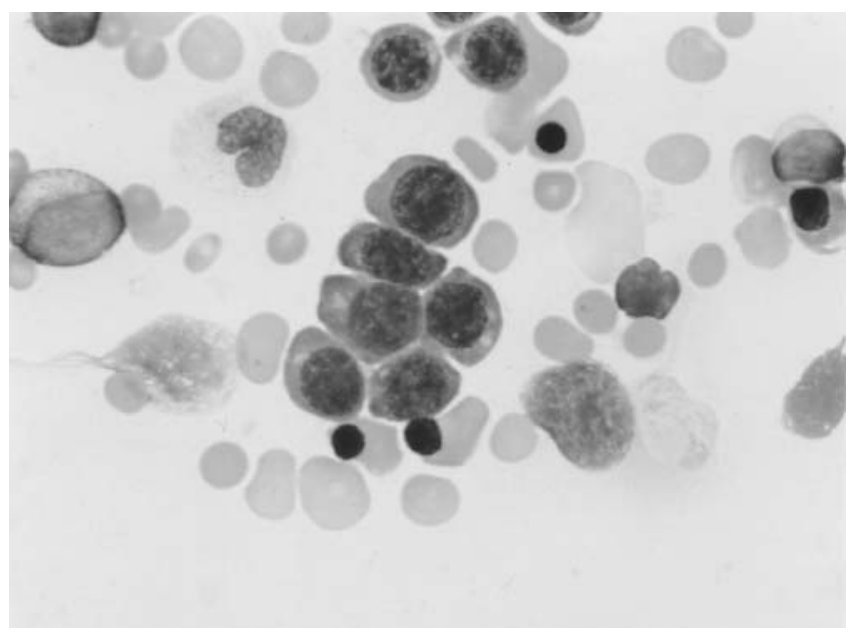

A

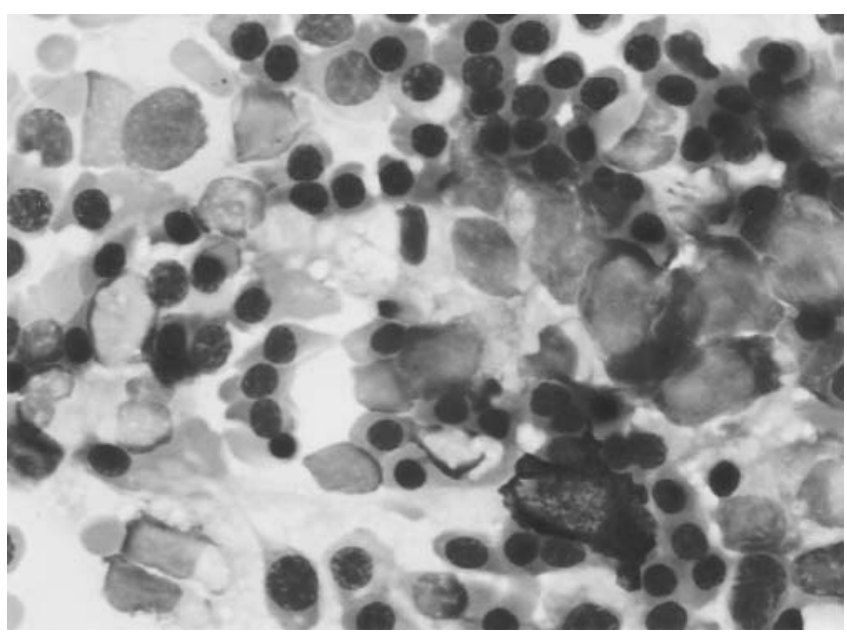

B

Figure 1. Bone marrow aspiration showed discrete hyperplasia of the erythropoietic system without malignant cells (A) and a "erythroblastic island", a few macrophages surrounded by many erythroblasts (B) (May-Giemsa staining $\times 1,000)$.

showed discrete hyperplasia of the erythropoietic system but revealed no signs of a lymphoproliferative disorder. The cold agglutinin was assumed to be I-specificity, because the antibody reacted more strongly with adult erythrocytes than with umbilical cord red blood cells. After adsorption of the unwanted cold agglutinins with the formaldehyde-treated rabbit blood cells, an indirect Coomb's test became negative. Therefore, we made a diagnosis of CAD, associated with SSc.

For the treatment, first of all, her room temperature was 
Cold Agglutinin Disease with SSc

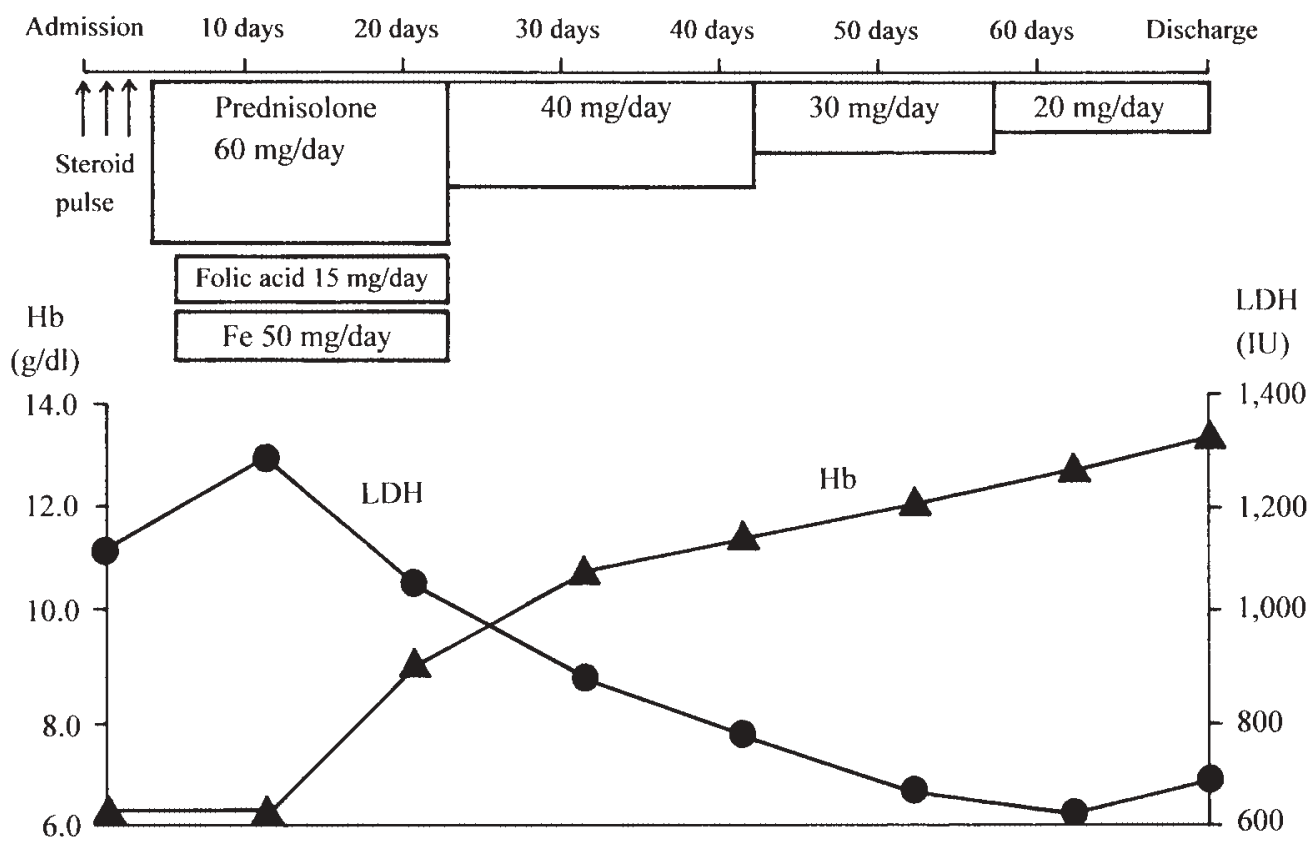

Figure 2. Clinical Course

kept at approximately $30^{\circ} \mathrm{C}$. We prescribed methylprednisolone $60 \mathrm{mg} /$ day, Fe $50 \mathrm{mg} / \mathrm{day}$, and folic acid $15 \mathrm{mg} / \mathrm{day}$ for three weeks, and her serum hemoglobin level increased to $9.0 \mathrm{~g} / \mathrm{dl}$. After tapering the corticosteroid therapy over 10 weeks to methylprednisolone $20 \mathrm{mg} / \mathrm{day}$, her serum hemoglobin level increased to $13.6 \mathrm{~g} / \mathrm{dl}$ with decreased reticulocytes $(57 / 1,000)$ and normalization of her serum haptoglobin level, $111 \mathrm{mg} / \mathrm{dl}$ (Fig. 2). The cold agglutinins became negative (titer $1: 4$ ) at a temperature of $25^{\circ} \mathrm{C}$. Subsequently, the acrocyanosis and Raynaud's phenomenon disappeared.

\section{Discussion}

Cold agglutinin syndrome is a hemolytic disorder characterized by the production of antibodies directed against specific antigens on the red blood cell membrane (5). Most cold agglutinins are $\operatorname{IgM}(6)$, although in rare cases $\operatorname{IgA}$ and $\operatorname{IgG}$ have been recorded (7). These antibodies are commonly directed against the I or i antigens on the red blood cell membrane (5) and in the majority of cases with CAD, cold agglutinins have the I-antigen specificity. Cold agglutinin is assigned I-specificity when the antibody reacts more strongly with adult erythrocytes than with umbilical cord red blood cells; conversely, i-specificity occurs when the cold agglutinin reacts more strongly with cord cells than with adult cells (8). Furthermore, adsorption by formaldehyde-fixed rabbit red cells is useful for detecting alloantibodies (anti-I, $\mathrm{H}$ and $\mathrm{IH})$ in patients whose serum contains strong cold autoagglutinins and who have recently been transfused or have a low hematocrit (9). When we adsorbed the unwanted cold agglutinins by this technique, an indirect Coomb's test was negative. Considering all the results, the cold agglutinin antibodies in the present case seemed to be polyclonal IgM with anti-I specificity.

There are two types of cold agglutinins: monoclonal and polyclonal antibodies $(2,10)$. Monoclonal antibodies are mostly found in patients with the "idiopathic" form or chronic CAD or with proliferative B-cell diseases. The "idiopathic" form is assumed to be far more common than the "secondary" form. Polyclonal antibodies are associated with the "secondary" form in the setting of an infectious disease, especially that caused by mycoplasma pneumoniae, or malignant non-Hodgkin lymphoma. These polyclonal forms are usually of a benign, transitory nature with low cold agglutinin titers (10).

Patients with CAD may experience severe discomfort during cold weather, with severe Raynaud-like symptoms and exacerbations of the hemolytic anemia. In this situation, hemolysis can occur as part of CAD, which may be accompanied by acrocyanosis and microvascular occlusions $(1,3$, 4). The severity of the clinical manifestations is regarded to be more strongly related to the thermal amplitude of the antibody than to the titre of the cold agglutinins (6). Moreover, the characteristics of low titer CAD reported previously were thermal amplitude at a higher temperature than in high-titer cold agglutinin disease, with a good response to steroid therapy (11). To date, only one case of severe AIHA with cold agglutinins associated with sclerodermic features has been described (12), in which case, CAD, autoimmune hemolytic anemia was considered to be secondarily caused by increasing disease activity of SSc. Considering that hemolysis is induced by cold agglutinins in vascular lumina, severe 


\section{OSHIMA et al}

Raynaud's phenomenon with SSc induced by a cold atmosphere seemed here to exacerbate the peripheral problems.

In most CAD patients, supportive care, such as cold avoidance, is sufficient to prevent the exacerbation of CAD (13). Therapy, therefore, is aimed at those patients with an underlying disease or for those with an exacerbation who are symptomatic from life-threatening, severe anemia. Corticosteroids remain the most effective long-term treatment for many patients with CAD (13). This is especially true in CAD patients with a low cold agglutinin titer, associated with Mycoplasma pneumoniae infection, hematologic malignancies, and collagen diseases (11). The anemia in the present case appeared to be caused by a rare pathogenesis, low-titer cold agglutinins, and was alleviated with the oral administration of prednisolone, with hemoglobin increased to the normal range.

In conclusion, this case demonstrated that hematological abnormalities are sometimes significantly related to the pathogenesis of epiphenomena associated with rheumatic disease.

\section{References}

1) Ulvestad E, Berentsen S, Bo K, Shammas FV. Clinical immunology of chronic cold agglutinin disease. Eur J Haematol 63: 259-266, 1999.

2) Berentsen S, Bo K, Shammas FV, Myking AO, Ulvestad E. Chronic cold agglutinin disease of the "idiopathic" type is a premalignant or low-grade malignant lymphoproliferative disease. APMIS 105: 354
362, 1997.

3) Marsman WA, Moore SB, Kondo M, et al. Do cold agglutinins have any impact on the outcome of liver transplantation? Transplantation 62: 1673-1676, 1996.

4) Nydegger UE, Kazatchkine MD, Miescher PA. Immunopathologic and clinical features of hemolytic anemia due to cold agglutinin. Semin Hematol 28: 66-77, 1991

5) Porras-Luque JI, Fernandez-Herrera J, Dauden E, et al. Cutaneous necrosis by cold agglutinins associated with glomeruloid reactive angioendotheliomatosis. Br J Dermatol 139: 1068-1072, 1998.

6) Crisp D, Pruzanski W. B-cell neoplasms with homogeneous coldreacting antibodies (cold agglutinins). Am J Med 72: 915-922, 1982.

7) Silberstein LE, Berkman EM, Schreiber AD. Cold hemagglutinin disease associated with IgG cold-reactive antibody. Ann Intern Med 106: 238-242, 1987.

8) Rosse W, Bunn HE. Hemolytic anemias. in: Harrison's Principles of Internal Medicine, Isselbacher KJ, Braunwald E, Wilson JD, et al., Eds., 13th edn, McGraw-Hill, New York, 1994: 1743-1754.

9) Marks MR, Reid ME, Ellisor SS, et al. Adsorption of unwanted cold autoagglutinins by formaldehyde-treated rabbit red blood cells. Transfusion 20: 629, 1980 (Abstract).

10) Lauchli S, Widmer L, Lautenschlager S. Cold agglutinin disease- the importance of cutaneous signs. Dermatology 202: 356-358, 2001.

11) Schreiber AD, Herskovitz BS, Goldwein M. Low-titer coldhemagglutinin disease. Mechanism of hemolysis and response to corticosteroids. N Engl J Med 296: 1490-1494, 1977.

12) Lugassy G, Reitblatt T, Ducach A, Oren S. Severe autoimmune hemolytic anemia with cold agglutinin and sclerodermic features-favorable response to danazol. Ann Hematol 67: 143-144, 1993.

13) Cao L, Kaiser P, Gustin D, Hoffman R, Feldman L. Cold agglutinin disease in a patient with uterine sarcoma. Am J Med Sci 320: 352-354, 2000. 